\title{
Hubungan Sosial Ekonomi Dan Tatus Gizi Dengan Kejadian Menarche Dini pada Anak Sekolah Siswi Kelas V dan VI di SDN 205 Kota Baru Kota Jambi
}

\author{
Hasyim Kadri ${ }^{1}$ \\ Sekolah Tinggi Ilmu Kesehatan Baiturrahim Jambi ${ }^{1}$
}

\begin{abstract}
Menarche is the beginning of menstruation in a girl at puberty, which usually appears at the age of 11-14 years. Menarche is a sign of a social status change from child to adolescent, adolescent girls who have a neurotic tendency in the age of puberty experience many mental conflicts with the arrival of the first menstruation that can lead to pathological behavior (Sukarni $k$, et al 2013), the occurrence of Menarche at each Women are not the same because there are several factors that influence it, including socio-economic factors, heredity, social environment and also health factors and nutritional status. Teenagers who are obese usually tend to experience Menarche earlier than thin young women (Andira, D. 2010). Data obtained in SDN 205 City Jambi amounted to 45 respondents. Research Objectives Knowledge of Social Environment Relationship, Socioeconomic Status, Nutrition Status and Media Period simultaneously with the incidence of Early Menarche In schoolchildren grade V and VI SDN 205 City District Baru City Jambi. The design of this research is qualitative with analytical survey research method, using Cross Sectional approach. Population in this research is all student of class V and VI which Menarche early at SDN 205 City Jambi. The sample in this study is the total (Total Sampling) of grade V and VI students who have Menarche in SDN 205 City Jambi which amounted to 45 Respondents. In this investigation, Univariate, Bivariate and Multivariate analyzes were conducted. The result of the analysis shows that there are social environment relation ( $p$ value 0.000 ), economic social ( $p$ value 0.000), nutritional status ( $p$ value 0.000) and mass media ( $p$ value 0.002). It is suggested to increase the counseling of Menarche early and Menarche pain to students and also to activate UKS activities.
\end{abstract}

Keywords: Nutrition Status Social Economy and Early Menarche

\section{PENDAHULUAN}

Menarche adalah permulaan menstruasi pada seorang gadis pada masa pubertas, yang biasanya muncul pada usia 11-14 tahun. Menarche merupakan pertanda adanya suatu perubahan status sosial dari anak-anak ke dewasa, remaja putri yang mempunyai kecenderungan neurotis dalam usia pubertas banyak mengalami konflik batin dengan datangnya menstruasi pertama yang dapat menimbulkan tingkah laku patologis (Sukarni k ,dkk 2013).

Usia saat seorang anak perempuan mulai mendapat menstruasi sangat bervariasi. Terdapat kecenderungan bahwa saat ini anak mendapat menstruasi pertama kali pada usia yang lebih muda. Ada yang berusia 12 tahun saat ia mendapat menstruasi pertama kali, tapi ada juga yang 8 tahun sudah memulai siklusnya. Bila usia 16 tahun baru mendapat menstruasi pun dapat terjadi (Proverawati A dan Misaroh S, 2009).

Usia untuk mencapai fase terjadinya menarche dipengaruhi oleh banyak faktor antara lain faktor suku, genetik, gizi, sosial, ekonomi. Di Inggris usia rata-rata untuk mencapai menarche adalah 13,1 tahun, sedangkan suku Bundi di Papua Nugini menarche dicapai pada usia 18,8 tahun. Anak wanita yang menderita kelainan tertentu selama dalam kandungan 452 
mendapatkan menarche pada usia lebih muda dari usia rata-rata. Sebaliknya anak wanita yang menderita cacat mental dan mongolisme akan mendapat menarche pada usia yang lebih lambat. Terjadinya penurunan usia dalam mendapatkan menarche sebagian besar dipengaruhi oleh adanya perbaikan gizi (Proverawati,A dan Misaroh, S. 2009).

Terjadinya menarche pada setiap wanita tidaklah sama karena ada beberapa faktor yang mempengaruhinya, antara lain faktor sosial-ekonomi, keturunan, lingkungan sosial dan juga faktor kesehatan dan status gizi. Remaja putri yang berbadan gemuk biasanya cenderung mengalami menarche lebih awal dari pada remaja putri yang berbadan kurus (Andira, D. 2010).

Penelitian Sarma Eko Natalia Sinaga, 2015 Hubungan Penghasilan Ayah dan Keterpaparan Media Dewasa dengan Status Menarche siswi SMP X di Rangkasbitung. Hubungan Penghasilan Ayah dengan Status Menarche Responden yang memiliki ayah dengan penghasilan kurang dari 5 juta $89,5 \%$ sudah Menarche, 86,2\% responden yang belum Menarche punya ayah dengan penghasilan kurang dari 5 juta. Nilai OR 1.36 artinya responden dengan ayah berpenghasilan kurang 5 juta 1.36 kali mempunyai anak yang sudah Menarche. Hubungan Keterpaparan Media Dewasa dengan Status Menarche 90,7\% responden yang terpapar media sudah mengalami Menarche dan 77.4 responden yang tidak terpapar sudah mengalami Menarche. Analisis hubungan keterpaparan media massa dan status Menarche dalam uji chi square memperlihatkan bahwa $\mathrm{p}$ value 0.111 $(>\alpha 0.05)$ yang berarti tidak ada hubungan bermakna antara keterpaparan media massa dewasa dengan status Menarche.

Survey awal yang dilakukan pada tanggal 22 Februari 2017 pada 20 siswi di SDN 205/, siswi yang menarche pada usia 8 tahun sebanyak 4 orang siswi, pada usia 9 tahun sebanyak 7 orang siswi, pada usia 10 tahun sebanyak 4 orang siswi dan pada usia 11 tahun sebanyak 5 orang siswi. Berdasarkan hasil wawancara kepada Kepala Sekolah dan guru BK di SDN 205 mengatakan bahwa rata-rata orang tua murid berprofesi sebagai buruh harian, guru honor, wiraswasta. hanya sedikit yang berprofesi sebagai PNS dengan karakteristik sosial ekonomi menengah ke bawah.

\section{METODE PENELITIAN}

Desain penelitian ini bersifat kuatitatif dengan metode penelitian survey analitik, dengan mengunakan pendekatan Cross Sectional, yaitu setiap objek penelitian diobservasi sekali saja dengan cara observasi atau pengumpulan data sekaligus pada suatu saat. Penelitian analitik karena ingin melihat hubungan antara variabel dependen dan variabel independen (Natoatmodjo, 2010). Penelitian ini telah dilaksanakan di SDN 205 Kecamatan Kota Baru Kota Jambi Tahun 2017.

Populasi dalam penelitian ini adalah seluruh siswi kelas V dan VI yang menarche dini di SDN 205 Kecamatan Kota Baru Kota Jambi. Jumlah populasi dalam penelitian ini di SDN 205 sebanyak 65 orang siswi. Sampel adalah keseluruhan objek yang akan diteliti dan dianggap mewakili seluruh populasi bila populasi $\leq 100$ maka sebaiknya diambil semua sebagai sampel dan bila populasi $\geq 100$ maka diambil $\geq 25 \%$ dari populasi (Arikunto 2014) Jadi Sampel dalam penelitian ini adalah seluruh (Total Sampling) siswi kelas V dan VI yang telah menarche di SDN 205 Kecamatan Kota Baru Kota Jambi yang berjumlah 45 orang.

Adapun kriteria inklusi dalam penelitian antara lain :

1. Siswi kelas V daVI yang telah menarche

2. Bersedia menjadi responden

3. Siswi yang belum dijadikan sampel di survey pendahuluan 
Pengumpulan data adalah suatu pendekatan terhadap responden dan proses pengumpulan karakteristik responden yang diperlukan dalam suatu penelitian (Notoadmodjo, 2007). Adapun alat pengumpulan data adalah menggunakan kuesioner, alat timbang badan dan alat ukur tinggi badan. Adapun data yang dipergunakan dalam penelitian ini diambil dari dua sumber yaitu dalam bentuk data primer dan data sekunder. Data primer adalah pengumpulan data yang dilakukan secara langsung terhadap responden melalui wawancara, pengukuran berat badan, tinggi badan dan pengisian kuesioner pada siswi kelas V dan IV SDN 205 yang sudah menarche. Sedangkan data sekunder di peroleh dari Dinas Pendidikan Kota Jambi, UPTD Pendidikan Kecamatan Kota Baru serta dari SDN 205 Kecamatan Kota Baru Kota Jambi.

Analisis data menggunakan univariat untuk mengetahui distribusi frekuensi dan persentase dari masing - masing variabel yang diteliti baik variabel dependen (Menarche dini) maupun variabel independen (Status Sosial Ekonomi, Status dan Gizi). Dan analisis bivariat Untuk mengatahui hubungan antara variabel dependen (Menarche dini) dengan variable independen (Status Sosial Ekonomi dan Status Gizi), sekaligus untuk melihat identifikasi variabel yang bermakna dengan menggunakan uji Chi- Square dengan komputerisasi dengan tingkat kepercayaan 95\% $(\alpha=0.05)$.

\section{HASIL DAN PEMBAHASAN Analisis Univariat}

Tabel 1 Distribusi Responden Menurut Usia Menarche pada Anak Sekolah Siswi Kelas V dan VI di SDN 205 Kota Baru Kota Jambi Tahun 2017

\begin{tabular}{clcc}
\hline No & Usia Menarche & Jumlah & \% \\
\hline 1 & Tidak Normal & 16 & 35,6 \\
2 & Normal & 29 & 64,4 \\
& Jumlah & $\mathbf{4 5}$ & $\mathbf{1 0 0}$ \\
\hline
\end{tabular}

Tabel 1 di atas terlihat bahwa responden umur yang tidak normal atau Menarche dini 16 orang( 35,6 \%) lebih sedikit dibandingkan dengan responden yang normal 29 orang $(64,4 \%)$.

Tabel 2 Distribusi Responden Menurut Sosial Ekonomi pada Anak Sekolah Siswi Kelas V dan VI di SDN 205 Kota Baru Kota Jambi Tahun 2017

\begin{tabular}{clcc}
\hline No & Sosial Ekonomi & Jumlah & \% \\
\hline 1 & Rendah & 25 & 55,6 \\
2 & Tinggi & 20 & 44,4 \\
& Jumlah & $\mathbf{4 5}$ & $\mathbf{1 0 0}$ \\
\hline
\end{tabular}

Menurut Tabel 2 di atas responden Sosial Ekonomi rendah 25 orang $(55,6 \%)$ lebih banyak dibandingkan dengan responden yang Sosial Ekonomi tinggi yaitu 20 orang $(44,4 \%)$

Tabel 3 Distribusi Responden Menurut Status Gizi pada Anak Sekolah Siswi Kelas V dan VI di SDN 205 Kota Baru Kota Jambi Tahun 2017

\begin{tabular}{clcc}
\hline No & Status Gizi & Jumlah & \% \\
\hline 1 & Tidak Ideal & 20 & 44,4 \\
2 & Ideal & 25 & 55,6 \\
& Jumlah & $\mathbf{4 5}$ & $\mathbf{1 0 0}$ \\
\hline
\end{tabular}

Berdasarkan Tabel 3 di atas responden Status Gizi tidak ideal 20 orang( 44,4 \%) lebih sedikit dibandingkan dengan responden yang Status Gizi ideal yaitu 25 orang $(55,6 \%)$

\section{Analisa Bivariat}

Untuk mengetahui apakah variabel independen berhubungan dengan variabel dependen, maka dilakukan analisa bivariat dengan menggunakan uji statistik ChiSquare dengan hasil sebagai berikut: 
Tabel 4 Distribusi Responden Menurut Sosial Ekonomi Terhadap Kejadian Menarche dini pada Anak Sekolah Siswi Kelas V dan VI di SDN 205 Kota Baru Kota Jambi Tahun 2017

\begin{tabular}{|c|c|c|c|c|c|c|c|c|c|}
\hline \multirow[t]{3}{*}{ No } & \multirow{3}{*}{$\begin{array}{c}\text { Sosial } \\
\text { Ekonomi }\end{array}$} & \multicolumn{4}{|c|}{ Usia Menarche } & \multicolumn{2}{|c|}{ Jumlah } & \multirow{3}{*}{$\begin{array}{c}\text { OR } \\
95 \% \mathrm{CI}\end{array}$} & \multirow[t]{3}{*}{$\mathrm{p}$-value } \\
\hline & & \multicolumn{2}{|c|}{ Tidak Normal } & \multicolumn{2}{|c|}{ Normal } & & & & \\
\hline & & $\mathrm{n}$ & $\%$ & $\mathrm{n}$ & $\%$ & $\mathrm{n}$ & $\%$ & & \\
\hline 1 & Rendah & 15 & 60,0 & 10 & 40,0 & 25 & 100 & 28,5 & 0,000 \\
\hline \multirow[t]{2}{*}{2} & Tinggi & 1 & 5,0 & 19 & 95,0 & 20 & 100 & $3,2-248,1$ & \\
\hline & Jumlah & 16 & 54,6 & 29 & 64,4 & 45 & 100 & & \\
\hline
\end{tabular}

Sumber : Data Primer SDN 205 Kota Baru Tahun 2017

Menurut analisis bivariat hubungan antara Sosial Ekonomi terhadap Usia Menarche dari 25 responden yang sosial ekonomi rendah ada sebanyak 15 orang $(60,0 \%)$ yang usia Menarche tidak normal atau Menarche dini dan 10 orang (40,0\%) usia Menarche normal. Dari 20 responden yang sosial ekonomi tinggi ada sebanyak 1 orang $(5,0 \%)$ yang usia Menarche tidak normal atau Menarche dini dan 19 orang $(95,0 \%)$ usia Menarche normal . Dari hasil
Uji statistik di peroleh $\rho$ value $=0,000$, maka dapat disimpulkan bahwa secara statistik pada alpa 5\% ada hubungan yang signifikan anatara sosial ekonomi terhadap Menarche dini pada anak sekolah siswi kelas V dan VI di SDN 205 Kota Baru Kota Jambi Tahun 2017. Dari analisis di dapat OR 28,50 artinya responden yang sosial ekonomi rendah mempunyai kecendrungan 28,50 kali usia Menarche tidak normal atau Menarche dini.

Tabel 5 Distribusi Responden Menurut Status Gizi Terhadap Kejadian Menarche dini pada Anak Sekolah Siswi Kelas V dan VI di SDN 205 Kota Baru Kota Jambi Tahun 2017

\begin{tabular}{|c|c|c|c|c|c|c|c|c|c|}
\hline \multirow[t]{3}{*}{ No } & \multirow{3}{*}{$\begin{array}{c}\text { Status } \\
\text { Gizi }\end{array}$} & \multicolumn{4}{|c|}{ Usia Menarche } & \multicolumn{2}{|c|}{ Jumlah } & \multirow{3}{*}{$\begin{array}{c}\text { OR } \\
95 \% \mathrm{CI}\end{array}$} & \multirow[t]{3}{*}{ p-value } \\
\hline & & \multicolumn{2}{|c|}{ Tidak Normal } & \multicolumn{2}{|c|}{ Normal } & & & & \\
\hline & & $\mathrm{n}$ & $\%$ & $\mathrm{n}$ & $\%$ & $\mathrm{n}$ & $\%$ & & \\
\hline 1 & Tidak Ideal & 15 & 75,0 & 5 & 25,0 & 20 & 100 & 72,0 & 0,000 \\
\hline \multirow[t]{2}{*}{2} & Ideal & 1 & 4,0 & 24 & 96,0 & 25 & 100 & $7,6-677,5$ & \\
\hline & Jumlah & 16 & 35,6 & 29 & 64,4 & 45 & 100 & & \\
\hline
\end{tabular}

Sumber : Data Primer SDN 205 Kota Baru Tahun 2017

Hasil analisis hubungan antara Sataus Gizi terhadap Usia Menarche dari 20 responden yang status gizi tidak ideal ada sebanyak 15 orang $(75,0 \%)$ yang usia Menarche tidak normal atau Menarche dini dan 5 orang $(25,0 \%)$ usia Menarche normal. Dari 25 responden yang status gizi ideal ada sebanyak 1 orang $(4,0 \%)$ yang usia Menarche tidak normal atau Menarche dini dan 24 orang $(96,0 \%)$ usia Menarche normal. Dari hasil Uji statistik di peroleh $\rho$ value $=0,000$ maka dapat disimpulkan bahwa secara statistik pada alpa 5\% ada hubungan yang signifikan anatara status gizi terhadap Menarche dini pada anak sekolah siswi kelas V dan VI di SDN 205 Kota Baru Kota Jambi Tahun 2017. Dari analisis di dapat OR 72,00 artinya responden yang status gizi tidak ideal mempunyai kecendrungan 72,00 kali usia Menarche tidak normal atau Menarche dini. 


\section{PEMBAHASAN}

Hubungan Sosial Ekonomi dengan Kejadian Menarche dini Pada Anak Sekolah Siswi Kelas V dan VI SDN 205 Kota Jambi Tahun 2017

Hasil analisis hubungan sosial ekonomi dengan kejadian menarche dini pada anak sekolah siswi SDN 205 Kota Jambi Tahun 2017 di peroleh bahwa dari 25 responden yang sosial ekonomi rendah yang mengalami kejadian menarche dini sebanyak 15 responden $(60,0 \%)$ dan yang tidak mengalami kejadian menarche dini sebanyak 10 responden $(40,0 \%)$. Sedangkan dari 20 responden yang sosial ekonomi tinggi yang mengalami kejadian menarche dini sebanyak 1 responden $(5,0 \%)$ dan yang tidak mengalami kejadian menarche dini sebanyak 19 orang $(95,0 \%)$.

Hasil uji statistik Chi-Square didapat nilai $p$ value 0,000 berarti $<\alpha(0,05)$, Hal ini menunjukkan bahwa ada hubungan yang signifikan antara sosial ekonomi dengan kejadian menarche dini di SDN 205 Kota Jambi Tahun 2017.

Dari hasil analisis diperoleh nilai OR : 28,500 artinya responden dengan sosial ekonomi rendah mempunyai peluang 28,500 kali untuk mengalami kejadian menarche dini dibanding responden dengan sosial ekonomi tinggi.

Terjadinya menarche pada setiap wanita tidaklah sama karena ada beberapa faktor yang mempengaruhinya, antara lain faktor sosial-ekonomi, keturunan, lingkungan sosial, dan juga faktor kesehatan dan status gizi. Remaja putri yang berbadan gemuk biasanya cenderung mengalami menarche lebih awal daripada remaja putri yang berbadan kurus (Andira, 2010).

Status sosial ekonomi merupakan sekumpulan hak dan kewajian yang dimiliki seseorang dalam masyarakatnya dan stratifikasi sosial menurut ekonomi yaitu meliputi sisi pendidikan dan pekerjaan karena pendidikan dan pekerjaan seseorang pada zaman sekarang sangat mempengaruhi kekayaan/perekonomian individu (Godam,2008).

Depkes RI, (2000) mengatakan bahwa faktor sosial ekonomi antara lain mencakup tentang pendapatan perkapita hubungan antara pendapatan perkapita dengan masalah kesehatan masyarakat biasanya bukan sebagai penyebab langsung. Namun lebih berkaitan dengan kemampuan keluarga dan menyediakan makanan bergizi, tempat tinggal yang memenuhi persyaratan kesehatan serta biaya untuk pemeliharaan kesehatan.

Hasil penelitian ini sejalan dengan penelitian Yuni Ernawati 2010 dengan Judul Faktor-faktor yang berhubungan dengan menarche dini pada siswi SDN. 215/IV dan SDN. 64/IV Kecamatan Kota Baru Jambi ini dilaksanakan di SDN. 215/IV dan SDN. 64/IV Kecamatan Kota Baru Jambi Tahun 2010 tentang hubungan status sosial ekonomi dan media massa dengan menarche dini di SDN. 215/IV dan SDN. 64/IV Kecamatan Kota Baru Jambi pada bulan Juli 2010. Metode penelitian adalah kuantitatif dengan desain Cross Sectional dan pengambilan sampel menggunakan total sampling dengan jumlah sampel 52 siswi. Pengambilan data dilakukan dengan melakukan wawancara menggunakan kuesioner dan hasil uji kuesioner dinyatakan valid dan reliabilitas apabila $\mathrm{r}$ hitung lebih besar dari $r$ tabel yaitu 0,444 . Uji satistik yang digunakan yaitu uji Chi-Square dengan menggunakan tingkat kemaknaan sebesar $5 \%(0,05)$. Hasil penelitian didapatkan bahwa menarche dini sebanyak 27 (51,9\%), tidak menarche dini sebanyak 25 (48,1\%), lingkungan sosial tidak baik sebanyak 28 $(53,8 \%)$ dan lingkungan sosial baik sebanyak $24(46,2 \%)$, status sosial ekonomi rendah sebanyak $27(51,9 \%)$ dan ekonomi tinggi $25(48,1 \%)$, media massa buruk sebanyak $32(61,5 \%)$ dan media massa baik $20(38,5 \%)$. Hasil penelitian dengan 456 
menggunakan uji Shi-Square dengan tingkat kemaknaan sebesar $5 \%$ didapatkan lingkungan sosial $(\mathrm{p}=0,006)$, status sosial ekonomi $(\mathrm{p}=0,013)$ dan media massa $(\mathrm{p}=0,027)$, maka dapat disimpulkan bahwa ada hubungan antara lingkungan sosial, status sosial ekonomi dan media massa dengan menarche dini di SDN. 215/IV dan SDN. 64/IV Kecamatan Kota Baru Jambi.

Menurut asumsi peneliti anak usia sekolah cenderung malas untuk menjaga kebersihan gigi dan mulutnya dengan cara menyikat gigi. Kebanyakan anak menyikat gigi hanya dilakukan $1 \mathrm{x}$ sehari pada saat mandi pagi, dan jarang untuk menyikat gigi pada malam hari selain itu anak juga kurang mengetahui bagaimana cara menyikat gigi dengan baik dan benar. Sehingga sisa-sisa makanan yang menempel disela-sela dan permukaan gigi yang tidak dibersihkan dengan baik akan menjadi plak, lama kelamaan plak akan mengeras dan kuman yang di dalam mulut akan memproduksi asam sehingga berkurangnya mineral dalam gigi dan menyebabkan karies gigi.

Maka perlu adanya peningkatan kesadaran dari orang tua untuk memperhatikan kebutuhan akan kesehatan anak agar tidak terjadi menarche dini.

\section{Hubungan Status Gizi dengan Kejadian Menarche Dini pada Anak Sekolah Siswi Kelas V dan VI SDN 205 Kota Jambi Tahun 2017}

Hasil analisis hubungan status gizi dengan kejadian menrche dini pada anak sekolah siswi SDN 205 Kota Jambi Tahun 2017 di peroleh bahwa dari 20 responden yang status gizi tidak ideal yang mengalami kejadian manarche dini sebanyak 15 responden $(75,0 \%)$ dan yang tidak mengalami kejadian manarche dini sebanyak 5 responden $(25,0 \%)$. Sedangkan dari 25 responden yang status gizi ideal yang mengalami kejadian manarche dini sebanyak 1 responden $(4,0 \%)$ dan yang tidak mengalami kejadian manarche dini sebanyak 24 responden $(96,0 \%)$.

Hasil uji statistik Chi-Square didapat nilai $p$ value 0,000 berarti $<\alpha(0,05)$. Hal ini menunjukkan bahwa ada hubungan yang signifikan antara status gizi dengan kejadian manarche dini di SDN 205 Kota Jambi Tahun 2017.

Hasil analisis diperoleh nilai OR : 72,000 artinya responden yang status gizi tidak ideal mempunyai peluang 72,000 kali untuk mengalami kejadian manarche dini dibanding responden yang status gizi ideal.

Pada masa remaja kudapan kontribusi $30 \%$ atau lebih dari total asupan kalori setiap hari. Remaja adalah masa peralihan dari anak menuju dewasa dimana terjadi pertumbuhan fisik, mental dan emosional yang sangat cepat. Makanan merupakan salahsatu kebutuhan manusia yang pokok bagi setiap orang. Makanan mengandung unsur zat gizi yang sangat diperlukan untuk tumbuh dan berkembang (Proverawati, A dan Asfuah, S 2009).

Status gizi remaja wanita sangat mempengaruhi terjadinya menarche baik faktor usia terjadinya menarche, adanya keluhan-keluhan maupun lamanya haid. Wanita secara psikologis yang pertama kali mengalami haid akan mengeluh nyeri, perutnya terasa pegal dan kurang nyaman. Tetapi ada juga remaja yang tidak merasakan hal itu dan itu semua karena asupan gizi yang adekuat. Gizi kurang atau terbatas akan mempengaruhi pertumbuhan fungsi organ tubuh yang akan menyebabkan terganggunya fungsi reproduksi. Hal ini akan mengakibatkan gangguan pada haid, tetapi akan berangsur baik bila asupan makanan bernutrisi baik (Proverawati, A dan Asfuah, S 2009).

Hasil penelitian menunjukan bahwa wanita yang mengalami menarche dini mempunyai berat badan maksimum $46 \mathrm{~kg}$. kelompok yang memiliki berat badan $37 \mathrm{~kg}$ mengalami merarche yang terlambat yaitu

Hubungan Sosial Ekonomi Dan Tatus Gizi Dengan Kejadian Menarche Dini pada Anak Sekolah Siswi Kelas V dan VI di SDN 205 Kota Baru Kota Jambi 
sekitar 4,5 $\mathrm{kg}$ lebih rendah dar kelompok yang memiliki berat badan yang ideal. (Proverawati, A dan Misaroh, S 2009)

Penelitian faktor-faktor berhubungan dengan status menarche dan usia menarche remaja putri usia (9-15) tahun pada siswi Sekolah Dasar dan Sekolah Lanjutan Tingkat Pertama di Jakarta Timur. Sampel diambil dari SDN 07 Petang dan SLTPN 258 Cibubur, SDN 03 Petang Pinang Ranti J1. Taman Mini Indonesia Indah dan SLTPN 20 Kramat Jati yang dianggap sebagai Sekolah dengan status sosial ekonomi kurang. Kemudian dari SD dan SLIP Islam AlMa'ruf Cibubur dan SDN IMP Jakarta dengan SLIP Lab School Rawamangun yang dianggap mewakili Sekolah dengan status sosial ekonomi tinggi. Faktor-faktor yang diteliti adalah status gizi (IMT), konsumsi makanan (sumber energi, karbohidrat, protein dan lemak), aktifitas olahraga, keterpaparan terhadap media informasi orang dewasa, usia menarche ibu dan status sosial ekonomi orang tua (pendidikan, pekerjaan, pendapatan orang tua), uang jajan siswi dan jumlah anggota keluarga yang hidup, Jenis penelitian ini adalah kuantitatif dengan rancangan penelitian yang digunakan adalah Cross Sectional. Besar sampel sebanyak 344 remaja putri yang diambil secara random dari 8 sekolah tersebut diatas. Analisis data meliputi analisis univariat, analisis bivariat untuk melihat distribusi dan hubungan setiap variabel dan analisis multivariat untuk melihat distribusi hubungan dan faktor apa paling dominan yang berhubungan dengan usia menarche, Diperoleh hasil bahwa dari 344 sampel 52,3 \% (180 responden) sudah menarche sisanya 47,7 \% (164 responden) belum menarche. Rata-rata usia menarche remaja putri adalah $147.3 \pm 114$ bulan $112.3 \pm 1.1$ tahun. Berdasarkan status sosiai ekonomi yang termasuk kedalam SES kurang $(\mathrm{n}=105)$ rata-rata usia menarche $151.06 \pm 35.9$ bulan $112.6 \pm 3$ tahun. Yang termasuk dalam SES tinggi ( $\mathrm{n}=75$ ) rata-rata usia menarche $141,96 \pm 24,04$ bulan $111,8 \pm 2$ tahun. Sedangkan dari variabel yang diteliti ternyata hasil uji bivariat menunjukkan hubungan yang bermakna antara status gizi, konsumsi energi, konsumsi protein, usia menarche ibu, pendidikan bapak, pendidikan ibu, pekerjaan bapak, pendapatan keluarga dan uang jajan dengan usia menarche remaja putri, dan variabel status gizi, konsumsi protein, konsumsi energi, frekuensi konsumsi makanan lain, aktifitas olahraga, keterpaparan dengan media informasi, pendidikan bapak, pekerjaan bapak dan uang jajan berhubungan bermakna dengan usia menarche (Bambang, 2004).

Kesimpulan usia sekolah pada wanita perlu mempertahankan status gizi yang baik dengan mengkonsumsi makanan seimbang karena sangat dibutuhkan pada saat haid. Ini dibuktikan dengan pada fase luteal akan terjadi peningkatan keburuhan nutrisi. Pada usia sekolah energi dan protein dibutuhkan lebih banyak dari pada orang dewasa, demikian pula vitamin dan mineral. Vitamin B1, B2 dan B6 sangat penting untuk metabolisme karbohidrat menjadi energi. Demikian pula asam folat dan vitamin B12 untuk pembentukan sel darah merah, dan vitamin A untuk pertumbuhan yang diperlukan oleh jaringan sehingga usia menarche bisa normal sesuai dengan umur.

\section{SIMPULAN}

Berdasarkan hasil penelitian diperoleh kesimpulan sebagai berikut :

1. Ada hubungan sosial ekonomi dengan kejadian menarche dini pada anak sekolah siswi kelas V dan VI SDN 205 Kecamatan Kota Baru Kota Jambi Tahun 2017 (p value 0,000)

2. Ada hubungan status gizi dengan kejadian menarche dini pada anak sekolah siswi kelas V dan VI SDN 205 Kecamatan Kota Baru Kota Jambi Tahun 2017 (p value 0,000) 


\section{DAFTAR PUSTAKA}

Ali, M dan Asrori. 2004. Sosial Ekonomi. Diakses pada tanggal 16 Maret 2017 jam 09.50 WIB.

Andira, D. 2010. Seluk-Beluk Kesehatan Reproduksi Wanita. A+Plus Books. Jogjakarta.

Arikunto, S. 2006. Prosedur Penelitian Suatu Pendekatan Praktik. Edisi Revisi IV. Rineka Cipta. Jakarta.

Arikunto, Suharsimi.2014.'Penelitian Tindakan Kelas". Jakarta:PT Bumi Aksara.

Bambang. 2004. Faktor-Faktor Yang Berhubungan Dengan Usia Menarche Remaja Putri (9 - 15 Tahun) Sekolah Lanjutan Tingkat Pertama di Jakarta Timur.

Bobak, M dan Irene et., al. 2004. Keperawatan Maternitas. Edisi 4. EGC. Jakarta.

Cunningham, Gary F. et al, 2005. Obstetri Williams. Edisi 21. Vol. 1. EGC. Jakarta.

Data Dinas Pendidikan Kota Jambi. 2016. Profil Kesehatan Provinsi Jambi

Ernawati, Y 2010 dengan Judul Faktorfaktor yang berhubungan dengan menarche dini pada siswi SDN. 215/iv dan SDN. 64/iv Kecamatan Kota Baru Jambi

Godam. 2008. Defenisi status sosial ekonomi. EGC. Jakarta.

Harahap, I. 2014 Faktor-Faktor Yang Berhubungan Dengan Menarche Pada Remaja Putri Di SMP Negeri 3 Kota Jambi

Hastono, S. P. (2001). Analisis Data. Jakarta: Universitas Indonesia

Hurlock, E.B (2002).Psikologi Perkembangan $.5^{\text {th }}$ edition. Erlanga: Jakarta.

Hidayat, A. Aziz Alimul. 2008. Metode Penelitian Keperawatan dan Teknik
Analisis Data. Salemba Medika Jakarta.

Kartono, 1992. Psikologi Wanita. Mengenal Gadis Remaja dan Wanita Dewasa. Mandar Maju. Bandung.

Kaspul, 2016. Ketetapan Upah Minimum Kota Jambi. Dinsosnaker Kota Jambi

Manuaba, 2007. Pengantar Kuliah Obstetri. EGC. Jakarta.

Notoatmodjo, S. 2007. Ilmu Kesehatan Masyarakat. Rineka Cipta. Jakarta.

Notoatmodjo, S. 2010. Prosedur Penelitian

Suatu Pendekatan Praktik. Rineka

Cipta. Jakarta.

Nugroho, T.dkk . 2014. Masalah Kesehatan

Reproduksi Wanita. Nuha Medika.

Yogyakarta

Owen Elizabeth, 2005. Panduan Kesehatan Bagi Wanita. Prestasi Pustakaraya. Jakarta.

Pacarada. M. et all. 2007. Impact Of SocioEconomic Factors On Onset Of Menarche In Girl. BMJ.

Prastyawati, dan Arsita Eka. 2012.

Kesehatan Ibu dan Anak (KIA) dalam

Milenium Development Goals

(MDGs). Nuha Medika. Yogyakarta

Prasetyawati, dan Arsita Eka. 2012.

Kesehatan Ibu dan Anak (KIA) dalam

Millenium Development Goals

(MDG'S). Yogyakarta : Nuha Medika

Proverawati A, dan Asfuah S, 2009. Buku Ajar Gizi untuk Kebidanan. Nuha Medika. Yogyakarta.

Proverawati A, dan Misaroh S, 2009. Menarche Menstruasi Pertama Penuh Makna. Nuha Medika. Yogyakarta.

Sinaga, N 2015 Hubungan Penghasilan Ayah dan Keterpaparan Media Dewasa dengan Status Menarche siswi SMP X di Rangkasbitung

Sarwono, Prawirohardjo, 2005. Buku Acuan Nasional Pelayanan Kesehatan Maternal dan Neonatal. JKPKKRPOGI. Jakarta. 
SDN 205 Kecamatan Kota Baru Kota Jambi

Tahun 2017

Sedyaningsih Rahayu E, 2010 Standar Antropometri Penilayan Status Gizi Anak. SK Mentri Kesehatan Republik Indonesia.

Senjaya, S, 2010. Media Massa Media Pendidikan. EGC : Jakarta

Siswono. 2004.Konsumsi Kalsium Cegah

Osteoporosis.http://www.mediaindo.co .id.

Sobarna. 2008. Perilaku Kekerasan pada Anak. EGC : Jakarta

Soetjiningsih. 2012. Tumbuh Kembang Anak. Penerbit Buku Kedokteran EGC. Jakarta

Sukarni K, dkk. 2013. Kehamilan

Pesrsalinan dan Nifas. Nuha Medika.

Yogyakarta

Wong, D,dkk. 2009. Buku Ajar

Keperawatan Pediatrik. Volume 1.

Penerbit Buku Kedokteran EGC :

Jakarta

UPTD Pendidikan Kecamatan Kota Baru

Kota Jambi Tahun 2016 